\title{
ANTI-INFLAMMATORY ACTIVITY OF METHANOL EXTRACT OF NIEBUHRIA APETALA (ROTH) DUNN - IN VITRO MODELS
}

\begin{abstract}
RAJESH A ${ }^{1}$, DOSS A ${ }^{2}$, TRESINA PS ${ }^{2}$, MOHAN VR ${ }^{3}$
${ }^{1}$ Department of Medicinal Botany, Government Siddha Medical College, Palyamkottai, Tamil Nadu, India. ${ }^{2}$ Department of Botany, V. 0. Chidambaram College, Tuticorin, Tamil Nadu, India. ${ }^{3}$ Department of Biomedical Science and Technology, Noorul Islam Centre for Higher Education, Kumaracoil, Tamil Nadu, India. Email: vrmohanvoc@gmail.com
\end{abstract}

Received: 11 February 2019, Revised and Accepted: 10 April 2019

ABSTRACT

Objective: The objective of this study was to determine the anti-inflammatory activity of methanol extract of Niebuhria apetala and its possible mechanism of action

Methods: Methanol extract of Niebuhria apetala leaf (NAL) was assessed for its anti-inflammatory activity by in vitro methods. Using albumin denaturation assay, proteinase inhibitory activity, membrane stabilization, and antilipoxygenase activity at different concentrations, in vitro antiinflammatory activity was estimated. The standard drug used for this purpose was aspirin.

Results: Methanol extract NAL at a concentration range of $100-500 \mu \mathrm{g} / \mathrm{ml}$ significant $(\mathrm{p}<0.01)$ protects the heat-induced protein denaturation. At the concentration of $500 \mathrm{mg} / \mathrm{ml}$, NAL showed significant $(\mathrm{p}<0.01)$ inhibition of protease inhibitory action. Heat-induced hemolysis of erythrocyte, hypotonicity-induced hemolysis, and lipooxygenase activity were significant $(\mathrm{p}<0.01)$ inhibited at the concentration of $500 \mu \mathrm{g} / \mathrm{ml}$.

Conclusion: Finally, the present study indicates that methanol extract of Niebuhria apetala can be a potential source of anti-inflammatory agent.

Keywords: Niebuhria apetala, Hypotonic, Human red blood cell, Antilipoxygenase.

(C) 2019 The Authors. Published by Innovare Academic Sciences Pvt Ltd. This is an open access article under the CC BY license (http://creativecommons. org/licenses/by/4. 0/) DOI: http://dx.doi.org/10.22159/ajpcr.2019.v12i5.32512

\section{INTRODUCTION}

Inflammation is a response to acute tissue damage resulting from physical injury, ischemic injury, infection exposure to toxins, or other types of trauma. It can play a role in tumor suppression by stimulating an antitumor immune response, but more often it appears to stimulate tumor development [1]. Lysosomal enzymes are released during inflammation. These enzymes produce a variety of disorders which lead to the tissue injury by damaging the macromolecules and lipid peroxidation of membranes. These damages are responsible for certain pathological conditions as heart attack, septic stocks and rheumatoid arthritis, etc. The extracellular activity of these enzymes is considered to be related to acute or chronic inflammation. Stabilization of lysosomal membrane is significant in limiting the inflammatory. This is response by inhibiting the release of lysosomal constituents of activated neutrophil such as bactericidal enzymes and proteases. They further cause tissue inflammation and damage on extracellular release or by stability the lysosomal membrane [2]. Inflammation is considered to be a complex process. This is frequently associated with pain and involves occurrences such as increase of protein denaturation, increase of vascular permeability, and membrane alteration. Erythrocyte membrane or human red blood cell (HRBC) is analogous to the lysosomal membrane. Its stabilization shows that the extract may as well stabilize lysosomal membranes. Stabilization of HRBC membrane by hypotonicity-induced membrane lysis can be taken as an in vitro measure of anti-inflammatory activity of the drug or plant extracts. After decades of serious thing with the modern medicinal system, people have started looking at the ancient medicinal systems such as Ayurveda, Siddha, and Unani. This is due to the adverse effects associated with synthetic drugs [3]. Herbal drugs play an important role in health-care programs, especially in developing countries. Herbal products are of interest to many patients and health-care practitioners because more than $70 \%$ of the world's population is relied on herbal medicines for part of their primary health-care system [4].
Capparis species is also known as caper plants. These are known as a potential cause of biochemical compounds and precious nutrients with physiological function. The various biological activities include antibacterial, hepatoprotective, anthelmintic, antifungal, antidiabetic, anti-inflammatory, anticancer, and antihyperlipidemic. These actions as well as folk medicinal uses of caper plants have been featured to the presence of functional bioactives, for example, phenolic acids, flavonoids, alkaloids, natural sugars, vitamins, phytosterols, and organic acids [5]. A survey of literature indicated that no systematic approach has been made to evaluate the anti-inflammatory potential of Niebuhria apetala by in vitro method. The present study involves the determination of in vitro anti-inflammatory activity of $N$. apetala by inhibition of albumin denaturation, antiproteinase action, membrane stabilization, and antilipoxygenase activity.

\section{MATERIALS AND METHODS}

$N$. apetala (Roth) Dunn leaves were collected in fresh from Pechiparai, Kanyakumari District, Tamil Nadu, India. The plant sample was found out with the help of local flora and confirmed by Botanical Survey of India, Southern Circle, Coimbatore, Tamil Nadu, India. A voucher specimen of composed plants was deposited in the Ethnopharmacology Unit, Post Graduate and Research Department of Botany, V. O. Chidambaram College, Thoothukudi District, Tamil Nadu, India.

\section{Solvent extraction}

Methanol was used as solvent to prepare the plant extracts. The leaves were directly soaked for $12 \mathrm{~h}$ in $500 \mathrm{ml}$ methanol and then subjected to extraction by refluxing for 6-8 $\mathrm{h}$ below the boiling point of the solvent. The ethanol extracts were concentrated by evaporating at a reduced pressure using rotary evaporator. The concentrated extracts were further dried at $37^{\circ} \mathrm{C}$ for 3-4 days to facilitate complete evaporation of the solvents. 
Assessment of in vitro anti-inflammatory activity Inhibition of albumin denaturation

The anti-inflammatory activity of $N$. apetala was premeditated using inhibition of albumin denaturation technique. This was calculated according to Mizushima and Kobayashi [6] and Sakat et al. [7] followed with minor modifications. The reaction mixture consists of test extracts and $1 \%$ aqueous solution of bovine albumin fraction. The $\mathrm{pH}$ of the reaction mixture was altered using small amount of $1 \mathrm{~N}$ hydrochloric acid $(\mathrm{HCl})$. The sample extracts were protected at $37^{\circ} \mathrm{C}$ for $20 \mathrm{~min}$. Then, it is heated at $51^{\circ} \mathrm{C}$ for $20 \mathrm{~min}$. After cooling the samples, the turbidity was calculated at $660 \mathrm{~nm}$. (Ultraviolet-Visible Spectrophotometer Model 371, Elico India Ltd.). The experiment was performed in triplicate.

The percentage inhibition of protein denaturation was computed as follows:

Percentage inhibition $=($ Abs Control - Abs Sample $) \times 100 /$ Abs control

\section{Antiproteinase action}

The test was performed according to the modified method of Oyedepo and Femurewa [8] and Sakat et al. [7]. The reaction mixture (2 $\mathrm{ml})$ was containing $1 \mathrm{ml} 20 \mathrm{mM}$ Tris-HCl buffer ( $\mathrm{pH} 7.4$ ), $0.06 \mathrm{mg}$ trypsin, and $1 \mathrm{ml}$ test sample of different concentrations $(100-500 \mu \mathrm{g} / \mathrm{ml})$. The mixture was kept warm at $37^{\circ} \mathrm{C}$ for $5 \mathrm{~min}$. To this, $1 \mathrm{ml}$ of $0.8 \%(\mathrm{w} / \mathrm{v}$ ) casein was added. The mixture was kept warm for an extra 20 min. $2 \mathrm{ml}$ of $70 \%$ perchloric acid was added to it to arrest the reaction. Followed by this, the cloudy suspension was centrifuged. Then, the absorbance of the supernatant was read at $210 \mathrm{~nm}$ against buffer as blank. The experiment was repeated thrice. The percentage inhibition of proteinase inhibitory activity was computed as follows.

Percentage inhibition $=($ Abs control - Abs sample $) \times 100 /$ Abs control

\section{Membrane stabilization}

Preparation of RBCs suspension [7,9]

The blood was collected from healthy human volunteer who has not taken any nonsteroidal anti-inflammatory drugs for 2 weeks before the experiment and transferred to the centrifuge tubes. At $3000 \mathrm{rpm}$ for $10 \mathrm{~min}$, the tubes were centrifuged and were washed 3 times with equal volume of normal saline. The volume of blood was determined and reconstituted as $10 \% \mathrm{v} / \mathrm{v}$ suspension with normal saline.

\section{Heat-induced hemolysis [7,10]}

The reaction mixture $(2 \mathrm{ml})$ consisted of $1 \mathrm{ml}$ test sample of dissimilar concentrations (100-500 $\mu \mathrm{g} / \mathrm{ml})$ and $1 \mathrm{ml}$ of $10 \%$ RBCs suspension, in its place of test sample, only saline was adjoined to the control test tube. Aspirin was used as standard drug. All the centrifuge tubes enclosing reaction mixture were incubated in water bath at $56^{\circ} \mathrm{C}$ for $30 \mathrm{~min}$. At the end of the incubation, the tubes were cooled using running tap water. At $2500 \mathrm{rpm}$ for $5 \mathrm{~min}$ and the absorbance of the supernatants was taken at $560 \mathrm{~nm}$, the reaction mixture was centrifuged. The experiment was completed in triplicates for all the test samples.

The percentage inhibition of hemolysis was computed as follows:

$\%$ inhibition of hemolysis $=($ Abs control-Abs sample $) \times 100 /$ Abs control

\section{Hypotonicity-induced hemolysis [11]}

Different reference samples, different concentrations of extract $(100-500 \mu \mathrm{g} / \mathrm{ml})$, and control were individually mixed with $2 \mathrm{ml}$ of hyposaline, $1 \mathrm{ml}$ of phosphate buffer, and $0.5 \mathrm{ml}$ of HRBC suspension. Diclofenac sodium $(100 \mu \mathrm{g} / \mathrm{ml})$ was utilized as a standard drug. All the assay mixtures were kept warm at $370^{\circ} \mathrm{C}$ for $30 \mathrm{~min}$ and then centrifuged at $3000 \mathrm{rpm}$. The supernatant liquid was poured and the hemoglobin content was approximated by a spectrophotometer at $560 \mathrm{~nm}$. The percentage hemolysis was calculated approximately by assuming the hemolysis produced in the control as $100 \%$.
Percentage protection of hemolysis=100-(OD sample/OD control) $\times 100$.

\section{Antilipoxygenase activity [10]}

Antilipoxygenase activity was considered using linoleic acid as substrate and lipoxidase as enzyme. Test samples were dissolved in $0.25 \mathrm{ml}$ of $2 \mathrm{M}$ borate buffer $\mathrm{pH} 9.0$ and additional $0.25 \mathrm{ml}$ of lipoxidase enzyme solution $(20,000 \mathrm{U} / \mathrm{ml})$ is added and kept warm for $5 \mathrm{~min}$ at $250^{\circ} \mathrm{C}$. After which, $1.0 \mathrm{ml}$ of linoleic acid solution $(0.6$ $\mathrm{mM}$ ) was added, mixed well and absorbance was measured at $234 \mathrm{~nm}$. Indomethacin was used as reference standard. The percentage inhibition was computed using the equation [(Abs control-Abs sample)/Abs control] $\times 100$.

A dose-response curve was plotted to establish the half-maximal inhibitory concentration $\left(\mathrm{IC}_{50}\right)$ values. $\mathrm{IC}_{50}$ is defined as the concentration sufficient to obtain $50 \%$ of a maximum scavenging capacity. All tests and analyses were repeated thrice and averaged.

\section{Statistical analysis}

Results are articulated as mean \pm standard deviation; the difference between experimental groups is compared by one-way analysis of variance (ANOVA). This is followed by Dunnett's multiple comparison test (control vs. test) making use of the software GraphPad Instat.

\section{RESULTS AND DISCUSSION}

\section{Phytochemical screening}

The preliminary phytochemical screening of methanol extract of $N$. apetala leaf revealed the presence of alkaloid, flavonoid, saponin, steroid, phenol, tannin, glycoside, and terpenoid.

\section{Inhibition of albumin denaturation}

Denaturation of proteins is a well-certificated cause of inflammation. The inflammatory drugs (salicylic acid, phenylbutazone, etc.) have shown dose-dependent ability to internally induce protein denaturation [6]. Protein denaturation is a process in which proteins

Table 1: Effect of NAL extract on heat-induced protein denaturation

\begin{tabular}{llll}
\hline Treatments & $\begin{array}{l}\text { Concentration } \\
(\mu \mathrm{g} / \mathrm{ml})\end{array}$ & $\begin{array}{l}\text { Absorbance } \\
\text { at } 660 \mathbf{~ n m}\end{array}$ & $\begin{array}{l}\text { \% inhibition } \\
\text { of protein } \\
\text { denaturation }\end{array}$ \\
\hline Control & - & $0.36 \pm 0.04$ & - \\
NAL & 100 & $0.31 \pm 0.06$ & 30 \\
NAL & 200 & $0.26 \pm 0.04^{* *}$ & 46 \\
NAL & 300 & $0.22 \pm 0.01^{* *}$ & 58 \\
NAL & 400 & $0.16 \pm 0.03^{* *}$ & 70 \\
NAL & 500 & $0.14 \pm 0.02^{* *}$ & 78 \\
Aspirin & 100 & $0.12 \pm 0.01^{* *}$ & 81 \\
\hline
\end{tabular}

Each value represents the mean \pm SD $n=3$, Experimental group was compared with control; ${ }^{* *} \mathrm{p}<0.01$ : Considered extremely significant; ns: not significant; NAL: Niebuhria apetala leaf, SD: Standard deviation

Table 2: Effect of NAL extract on proteinase inhibition action

\begin{tabular}{llll}
\hline Treatments & $\begin{array}{l}\text { Concentration } \\
(\boldsymbol{\mu g} / \mathbf{m l})\end{array}$ & $\begin{array}{l}\text { Absorbance } \\
\text { at } 660 \mathbf{~ n m}\end{array}$ & $\begin{array}{l}\text { \% inhibition } \\
\text { of protein } \\
\text { denaturation }\end{array}$ \\
\hline Control & - & $0.37 \pm 0.06$ & - \\
NAL & 100 & $0.34 \pm 0.03 \mathrm{~ns}$ & 24 \\
NAL & 200 & $0.28 \pm 0.01^{*}$ & 28 \\
NAL & 300 & $0.24 \pm 0.03^{* *}$ & 37 \\
NAL & 400 & $0.19 \pm 0.01^{* *}$ & 42 \\
NAL & 500 & $0.16 \pm 0.03^{* *}$ & 58 \\
Aspirin & 100 & $0.14 \pm 0.01^{* *}$ & 62 \\
\hline
\end{tabular}

Each value represents the mean $\pm S D n=3$, Experimental group was compared with control; ${ }^{* *} \mathrm{p}<0.01$ : Considered extremely significant; $P<0.05$ : considered significant; NS: not significant; NAL: Niebuhria apetala leaf, SD: Standard deviation 
lose their tertiary structure and secondary structure by application of external stress or compound. A majority of the biological proteins lose their biological function when denatured. As a part of the investigation on the mechanism of the anti-inflammatory movement, ability of plant extract to inhibit protein denaturation was calculated. It was effective in inhibitory heat-induced albumin denaturation. Maximum inhibition of $78 \%$ was observed at $500 \mu \mathrm{g} / \mathrm{ml}$. Aspirin, a standard anti-inflammatory drug, showed the maximum inhibition of $81 \%$ at the concentration of $100 \mu \mathrm{g} / \mathrm{ml}$ compared to control (Table 1 ).

\section{Proteinase inhibitory action}

Proteinases have been implicated in arthritic reactions. Neutrophils are known to be a rich resource of proteinase which bears in their lysosomal granules. It was previously reported that leukocytes proteinase plays an important role in the development of tissue damage during inflammatory reactions and significant level of protection was provided by proteinase [12]. Methanol extract of Niebuhria apetala leaf (NAL) exhibited significant antiproteinase activity at different concentrations as shown in Table 2. It showed maximum inhibition of $58 \%$ at $500 \mu \mathrm{g} / \mathrm{ml}$. Aspirin showed the maximum inhibition of $62 \%$ at $100 \mu \mathrm{g} / \mathrm{ml}$.

\section{Membrane stabilization}

The erythrocyte membrane may be considered a model of the lysosomal membrane which plays an important role in inflammation. The compounds which present the lysis of membrane originated by the release of hydrolytic enzymes contained within the lysosomes may relieve few systems of inflammation [13]. When the HRBC is made to hypotonic stress, the hemoglobin release from RBC will be there by anti-inflammatory drugs for the reason that of the membrane stabilization. It has been revealed that some herbal preparations were accomplished of stabilizing the RBS membrane. This may be analytical of their ability to put forth anti-inflammatory activity.

\section{Heat-induced hemolysis}

The methanol extract of NAL was effective inhibitory the heatinduced hemolysis at different concentrations. The results showed that methanol extract of NAL at a concentration of $500 \mu \mathrm{g} / \mathrm{ml}$ protect significantly $(\mathrm{p}<0.01)$ the erythrocyte membrane against lysis induced by heat (Table 3). Aspirin $100 \mu \mathrm{g} / \mathrm{ml}$ showed significant $(\mathrm{p}<0.01)$ protection against damaging effect of heat solution.

\section{Hypotonicity-induced hemolysis}

The results showed that methanol extract of NAL ata concentration of $200-500 \mu \mathrm{g} / \mathrm{ml}$ protect significantly $(\mathrm{p}=0.01)$ the erythrocyte membrane against lysis induced by hypotonic solution (Table 4). Aspirin $(500 \mu \mathrm{g} / \mathrm{ml})$ showed a significant $(\mathrm{p}<0.01)$ protects against the damaging effect of hypotonic solution. In the concentration of $500 \mu \mathrm{g} / \mathrm{ml}$, methanol extract of NAL showed maximum of $82 \%$ protection, where aspirin $(100 \mu \mathrm{g} / \mathrm{ml})$ showed $68 \%$ inhibition of RBC hemolysis when compared with control.

\section{Antilipoxygenase activity}

The plant lipoxygenase pathway is in many respects equivalent to the arachidonic acid cascades in animals [14]. For this reason, the in vivo inhibition of lipoxygenase constitutes a good model for the screening of plants with anti-inflammatory potentials [15]. Liquid oxygens (LOXs) are sensitive to antioxidants and most of their action may be inhibition of lipid hydroperoxide formation due to scavenging of lipidoxy or lipid peroxy radical formed in convert of enzyme peroxidation. This can limit the accessibility of lipid hydroperoxide substrate necessary for the catalytic cycle of LOX.

Methanol extract of NAL has been checked at 100, 200, 300, 400, and $500 \mu \mathrm{g} / \mathrm{ml}$; it showed $5,12,28,42$, and $64 \%$ antilipoxygenase activity, respectively. From this result, the strongest inhibition was obtained at a concentration of $500 \mu \mathrm{g} / \mathrm{ml}$. The standard aspirin showed $84 \%$ inhibition at a concentration of $100 \mu \mathrm{g} / \mathrm{ml}$ (Table 5).
Table 3: Effect of NAL extract on heat-induced hemolysis of erythrocyte

\begin{tabular}{llll}
\hline Treatments & $\begin{array}{l}\text { Concentration } \\
(\mu \mathrm{g} / \mathrm{ml})\end{array}$ & $\begin{array}{l}\text { Absorbance } \\
\text { at } 660 \mathbf{~ n m}\end{array}$ & $\begin{array}{l}\text { \% inhibition } \\
\text { of protein } \\
\text { denaturation }\end{array}$ \\
\hline Control & - & $0.33 \pm 0.02$ & - \\
NAL & 100 & $0.30 \pm 0.01$ & 16 \\
NAL & 200 & $0.28 \pm 0.03^{* *}$ & 20 \\
NAL & 300 & $0.24 \pm 0.01^{* *}$ & 34 \\
NAL & 400 & $0.20 \pm 0.02^{* *}$ & 40 \\
NAL & 500 & $0.13 \pm 0.03^{* *}$ & 59 \\
Aspirin & 100 & $0.07 \pm 0.01^{* *}$ & 72 \\
\hline
\end{tabular}

Each value represents the mean $\pm S D n=3$, Experimental group was compared with control; ${ }^{* *} \mathrm{p}<0.01$ : Considered extremely significant; ns: not significant; NAL: Niebuhria apetala leaf, SD: Standard deviation

Table 4: Effect of NAL extract on hypotonicity-induced hemolysis of erythrocytes

\begin{tabular}{llll}
\hline Treatments & $\begin{array}{l}\text { Concentration } \\
(\mu \mathrm{g} / \mathrm{ml})\end{array}$ & $\begin{array}{l}\text { Absorbance } \\
\text { at } 660 \mathbf{~ n m}\end{array}$ & $\begin{array}{l}\text { \% inhibition } \\
\text { of protein } \\
\text { denaturation }\end{array}$ \\
\hline Control & - & $0.32 \pm 0.07$ & - \\
NAL & 100 & $0.24 \pm 0.01 \mathrm{~ns}$ & 31 \\
NAL & 200 & $0.18 \pm 0.03^{* *}$ & 42 \\
NAL & 300 & $0.15 \pm 0.01^{* *}$ & 58 \\
NAL & 400 & $0.11 \pm 0.03^{* *}$ & 71 \\
NAL & 500 & $0.06 \pm 0.01^{* *}$ & 82 \\
Aspirin & 100 & $0.10 \pm 0.02^{* *}$ & 68 \\
\hline
\end{tabular}

Each value represents the mean \pm SD $n=3$, Experimental group was compared with control; ${ }^{* *} \mathrm{p}<0.01$ : Considered extremely significant; ns: not significant; NAL: Niebuhria apetala leaf, SD: Standard deviation

Table 5: Effect of NAL extract on lipoxygenase inhibitory action

\begin{tabular}{llll}
\hline Treatments & $\begin{array}{l}\text { Concentration } \\
(\boldsymbol{\mu g} / \mathbf{m l})\end{array}$ & $\begin{array}{l}\text { Absorbance } \\
\text { at } 660 \mathbf{~ n m}\end{array}$ & $\begin{array}{l}\text { \% inhibition } \\
\text { of protein } \\
\text { denaturation }\end{array}$ \\
\hline Control & - & $0.40 \pm 0.02$ & - \\
NAL & 100 & $0.38 \pm 0.03 \mathrm{~ns}$ & 05 \\
NAL & 200 & $0.32 \pm 0.05 \mathrm{~ns}$ & 12 \\
NAL & 300 & $0.26 \pm 0.04^{* *}$ & 28 \\
NAL & 400 & $020 \pm 0.03^{* *}$ & 42 \\
NAL & 500 & $0.14 \pm 0.02^{* *}$ & 64 \\
Aspirin & 100 & $0.07 \pm 0.01^{* *}$ & 84 \\
\hline
\end{tabular}

Each value represents the mean $\pm S D n=3$, Experimental group was compared with control; ${ }^{* *} \mathrm{p}<0.01$ : Considered extremely significant; ${ }^{*} \mathrm{p}<0.05$ : considered significant; ns: not significant; NAL: Niebuhria apetala leaf, SD: Standard deviation

\section{CONCLUSION}

In the present study, results indicated that the methanol extract of NAL possesses anti-inflammatory properties. These activities may be due to the presence of secondary metabolites such as alkaloids, flavonoids, tannins, steroids, and phenols. Further investigations are required to find active component of NAL extract and to confirm the mechanism of action.

\section{AUTHORS' CONTRIBUTIONS}

Dr. A Rajesh: Experimental part analysis and implementation, Dr. A Doss: Drafting of article, Dr. P Tresina Soris: Literature review, and Dr. V R Mohan: Concept, experimental design, and supervision.

\section{CONFLICTS OF INTEREST}

The authors declare that there are no conflicts of interest. 


\section{REFERENCES}

1. Prabhu VV, Guruvayoorappan C. Anti-inflammatory and anti-tumor activity of the marine mangrove Rhizophora apiculata. J Immunotoxicol 2012;9:341-52.

2. Rajendran V, Lakshmi KS. In vitro and in vivo anti-inflammatory activity of leaves of Symplocos cochinchnensis (Lour) Moore ssp Laurina. Bangladesh J Pharmacol 2008;3:121-4.

3. Yasmine Y, Caroline Jeba R. In vitro cytotoxicity activity of hydroalcoholic extract of polyherbal Churnam (Cofri) in normal liver and kidney cell lines. Asian J Pharm Clin Res 2019;12:74-7.

4. Supriya J, Kishor G, Aniket G. Phytochemical screening and antimicrobial activity of Portulaca quadrifida Linn. Asian J Pharm Clin Res 2019;12:78-81.

5. Ambati RR, Phang SM, Ravi S, Aswathanarayana RG. Astaxanthin: Sources, extraction, stability, biological activities and its commercial applications a review. Mar Drugs 2014;12:128-52.

6. Mizushima Y, Kobayashi M. Interaction of anti-inflammatory drugs with serum proteins, especially with some biologically active proteins. J Pharm Pharmacol 1968;20:169-73.

7. Sakat S, Juvekar AR, Gambhire MN. In vitro antioxidant and antiinflammatory activity of methanol extract of Oxalis corniculata Linn. Int J Pharma and Pharmacol Sci 2010;2:146-55.
8. Oyedepo OO, Femurewa AJ. Anti-protease and membrane stabilizing activities of extracts of fagra zanthoxiloides, Olax subscorpioides and Tetrapleura tetraptera. Int J of Pharmacong 1995;33:65-9.

9. Sadique J, Al-Rqobahs WA, Bughaith, EI-Gindi Ar. The bioactivity of certain medicinal plants on the stabilization of RBS membrane system. Fitoterapia 1989;60:525-32.

10. Shinde UA, Kulkarni KR, Phadke AS, Nair AM, Mungantiwar AA, Dikshit VJ, et al. Mast cell stabilizing and lipoxygenase inhibitory activity of Cedrus deodara (Roxb.) loud. Wood oil. Ind J Exp Biol 1999;37:258-61.

11. Azeem AK, Dilip C, Prasanth SS, Junise V, Shahima H. Antiinflammatory activity of the glandular extracts of Thunnus alalunga. Asia Pac J Med 2010;3:412-20.

12. Das SN, Chatterjee S. Long term toxicity study of ART-400. Ind Indg Med 1995;16:117-23.

13. Hess SM, Milloning RC. In: Lepow LH, Wards PA, editors. Inflammation, Mechanism and Control. New York: Academic Press; 1972. p. 1-72.

14. Gardner HW. Recent investigations into the lipoxygenase pathway of plants. Biochim Biophys Acta 1991;1084:221-39.

15. Abad MJ, Bermejo P, Villar A. The activity of flavonoids extracted from Tanacetum microphyllum DC. (Compositae) on soybean lipoxygenase and prostaglandin synthetase. Gen Pharmacol 1995;26:815-9. 